\title{
Hepatic Protein Synthesis in Suckling Rats: Effects of Stage of Development and Fasting
}

\author{
D. G. BURRIN, T. A. DAVIS, M. L. FIOROTTO, AND P. J. REEDS \\ USDA/ARS Children's Nutrition Research Center, Department of Pediatrics, Baylor College of Medicine, \\ Houston, Texas 77030
}

\begin{abstract}
We studied the developmental changes in hepatic protein synthesis in suckling rats between postpartum $\mathrm{d} 1$ and 28 and investigated the effect of fasting for 10 or $18 \mathrm{~h}$ on hepatic protein turnover at postpartum d 5,10 , 16 , and 28 . Fractional protein synthesis rates $\left(K_{S}, \% / d\right)$ were measured in vivo using a flooding dose of $\mathrm{L}-\left[4-{ }^{3} \mathrm{H}\right]$ phenylalanine. Although hepatic $K_{S}$ and translation efficiency (protein synthesis/unit RNA) were significantly higher at postpartum $d \mathbf{2 8}$ than $d \mathbf{1}$, the pattern of change was biphasic: $K_{S}$ and translational efficiency were higher at $d \mathbf{1 0}$ and 28 than at $\mathrm{d} 5$ and 16. The largest increase in $K_{S}$ and translational efficiency occurred during the period normally associated with weaning (between postpartum d 16 and 28). At all stages of development, the $K_{s}$ and translational efficiency in fasted rats were significantly lower than those in control (fed) rats, although the relative decline in both measurements was largest at postpartum d 10. The absolute rates of hepatic protein synthesis declined to similar levels on $\mathrm{d} \mathrm{5,10}$, and 16 after $10 \mathrm{~h}$ of fasting and changed little after $18 \mathrm{~h}$ of fasting; this level was significantly higher at postpartum d 28 . Our results suggest that postnatal development in suckling rats was marked by a biphasic pattern in the rates of hepatic protein synthesis, which increased during the neonatal and weaning periods. The relative changes in the synthesis and loss of hepatic protein in response to fasting were greater during the neonatal than during the late suckling and weaning periods. (Pediatr Res 31: 247-252, 1992)
\end{abstract}

\section{Abbreviations}

$\mathrm{K}_{\mathrm{S}}$, fractional synthesis rate

ASR, absolute synthesis rate

rASR, relative absolute synthesis rate

PCA, perchloric acid

EBW, empty body weight

The liver undergoes significant changes in growth and functional development from birth through weaning. Hepatic growth in suckling rats has been characterized as hyperplastic shortly after birth and as hypertrophic at weaning $(1,2)$. Postnatal changes in functional development include those in hepatic

Received July 23, 1991 ; accepted November 11, 1991.

Correspondence: Douglas G. Burrin, Ph.D., Children's Nutrition Research Center, 1100 Bates Street, Houston, TX 77030.

This is a publication of the USDA/ARS Children's Nutrition Research Center Department of Pediatrics, Baylor College of Medicine and Texas Children's Hospital, Houston, TX. This project was funded with federal funds from the United States Department of Agriculture, Agricultural Research Service under Cooperative Agreement number 58-6250-1-003. The contents of this publication do not necessarily reflect the views or policies of the U.S. Department of Agriculture, nor does mention of trade names, commercial products, or organizations imply endorsement by the U.S. Government. enzyme expression, which occur in two clusters during the neonatal and late suckling periods (3). The neonatal period between birth and $10 \mathrm{~d}$ of age is marked by an increase in the expression of hepatic enzymes involved in gluconeogenesis and fatty acid oxidation in response to the high fat, low carbohydrate composition of milk. During the transition from suckling to weaning, however, an increase occurs in the expression of lipogenic and ureagenic enzymes as the proportion of dietary carbohydrates increases.

In addition to dietary changes during the late suckling period, circulating thyroxine, corticosterone, and insulin concentrations increase, all of which play a regulatory role in the expression of hepatic enzyme activities (4). The changes in hepatic enzyme expression necessarily involve changes in the relative rates of mRNA and protein synthesis or turnover. Studies in growing weaned rats have shown that thyroxine and corticosterone can increase the expression of specific hepatic enzyme mRNA $(5,6)$ and increase hepatic protein synthesis (7). Despite documented changes in metabolic and endocrine status between birth and weaning, the ontogeny of hepatic protein synthesis is poorly understood.

During periods of acute starvation or fasting, however, conservation of body protein mass is crucial. A short-term fast ( $24 \mathrm{~h})$ in young growing and adult rats reduces the hepatic protein synthesis rate and protein mass by approximately 30 and $20 \%$, respectively $(8-10)$. Alternatively, in skeletal muscle, reduced protein synthesis in response to a short-term fast is greater in young rats than in older weaned rats $(11,12)$. Given the inherent metabolic fragility of the neonate, the conservation and maintenance of hepatic protein mass and perhaps hepatic function may be crucial during periods of acute nutrient deprivation.

On the basis of these observations, our study was designed to answer two questions: 1) Do changes in hepatic protein synthesis accompany the ontogenic changes in the composition of the diet and the concentrations of circulating hormones, and 2) is the effect of fasting on hepatic protein mass and synthesis influenced by stage of development?

\section{MATERIALS AND METHODS}

Experimental Design. Experiment 1. A more complete description of the animals and techniques has been reported (13). Sprague-Dawley rats (Charles River Laboratories, Wilmington, MA) with timed pregnancies were obtained at $14 \mathrm{~d}$ of gestation. Each dam was housed individually in a solid-bottom cage with wood-chip bedding and maintained in a temperature-controlled room at $23^{\circ} \mathrm{C}$ with a 12 -h on $(0400-1600 \mathrm{~h})$-off $(1600-0400 \mathrm{~h})$ light cycle. Animals had free access to deionized water and food (22\% protein, 5\% fat; Wayne Research Animal Diets, Chicago, IL). At $1 \mathrm{~d}$ of age, litters were standardized to 10 pups and weighed every $3 \mathrm{~d}$ thereafter. In the period from 1 to $20 \mathrm{~d}$ of age, pups and dams were housed such that the food was available to both. At $21 \mathrm{~d}$ of age, pups were physically separated from their dams and housed together as a litter in cages with free access to 


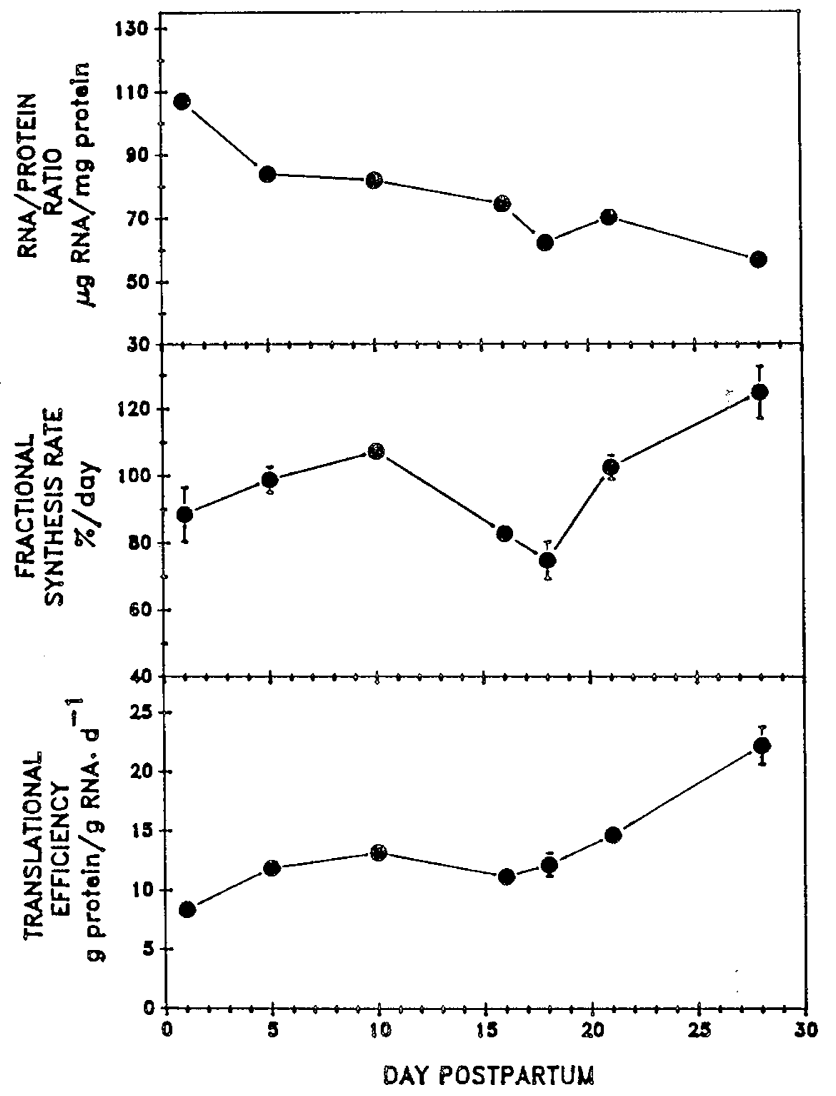

Fig. 1. Developmental changes in RNA protein ratio, $\mathrm{K}_{\mathrm{S}}$, and translational efficiency in hepatic tissue of suckling rats. RNA protein ratios were different $(p<0.01) \mathrm{d} 1$ vs 5 , d 5 vs 18 , and $\mathrm{d} 21$ vs 28 ; $\mathrm{K}_{\mathrm{s}}$ were different $(p<0.05) \mathrm{d} 1$ vs 10 , d $10 v s 18$, and d $18 v s 28$ (postpartum day effect, cubic $p<0.10$ ); translational efficiencies were different $(p<$ 0.01 ) $\mathrm{d} 1$ vs 18 and $\mathrm{d} 16$ vs 28 (postpartum day effect, quadratic $p<$ $0.05)$. Values are means $\pm \operatorname{SEM}(n=8)$. Data were analyzed by $t$ test and analysis of variance.

water and food as described above for dams. Pups were randomly selected from two litters used for each day and were studied between 0900 and $1200 \mathrm{~h}$ on $\mathrm{d} 1,5,10,16,18,21$, and 28 postpartum.

Experiment 2. A second set of litters was used to study the effect of fasting and was housed in the same manner as that in experiment 1 . Animals in experiment 2 were fed Purina Rodent Chow (Ralston-Purina Co., St. Louis, MO) (22.5\% protein, $4 \%$ fat) and water ad libitum. All litters were standardized to 10 pups within $1 \mathrm{~d}$ of birth. At postpartum d 5, 10, 16, and 28, pups from three litters were randomly assigned to one of three treatment groups and were studied during both normal feeding and after a period of 10 or $18 \mathrm{~h}$ of fasting. On postpartum $\mathrm{d} \mathrm{4,9}$, and 15 , the normally fed control pups were studied at $2000 \mathrm{~h}$. The remaining dams were separated from their respective pups at $2200 \mathrm{~h}$ and the dams' mammary ducts were surgically ligated under ether anesthesia; dams were then returned to their pups for the remainder of the experiment. The elapsed time between removal of the dam for surgery and return to her pups was approximately $30 \mathrm{~min}$. The following day, the remaining pups in each of the three litters were studied after $10 \mathrm{~h}(0800 \mathrm{~h})$ or 18 $\mathrm{h}(1600 \mathrm{~h})$ of fasting. Rats studied at $28 \mathrm{~d}$ were separated from their respective dams at postpartum $\mathrm{d} 21$ and fed Rodent Chow ad libitum. These rats were fasted by removing the food from their cages and were studied in the same manner as those on postpartum $\mathrm{d} 5,10$, and 16 . To verify that each pup had been fasted, stomach contents were measured after the animals were killed. Fasted pups whose stomach contents amounted to more than $25 \%$ of the average contents found in control (fed) pups were excluded from further analysis. The protocol was approved by the Animal Care and Use Committee of Baylor College of Medicine and was conducted in accordance with the National Research Council's Guide for the Care and Use of Laboratory Animals.

Measurement of In Vivo Protein Synthesis. Rats were decapitated, and trunk blood was obtained 2 and $10 \mathrm{~min}$ after a flooding dose of $\mathrm{L}-\left[4-{ }^{3} \mathrm{H}\right]$ phenylalanine $(50-100 \mu \mathrm{Ci} / \mathrm{rat}, 150 \mu \mathrm{mol} / \mathrm{mL} /$ $100 \mathrm{~g}$ body wt) was administered i.v. The peritoneal cavity was immediately flushed with ice-cold PBS $\left(\mathrm{CaCl}_{2}, 0.90 \mathrm{mM} ; \mathrm{KCl}\right.$, $2.68 \mathrm{mM} ; \mathrm{KH}_{2} \mathrm{PO}_{4}, 1.47 \mathrm{mM} ; \mathrm{MgCl}_{2} \cdot \mathrm{H}_{2} \mathrm{O}, 0.88 \mathrm{mM} ; \mathrm{NaCl}$, $137 \mathrm{mM} ; \mathrm{Na}_{2} \mathrm{HPO}_{4} \cdot 7 \mathrm{H}_{2} \mathrm{O}, 15.22 \mathrm{mM}$ ), pH 7.4. The liver was removed and weighed and a subsample was frozen in liquid nitrogen.

Tissue Preparation and Analysis. Liver samples were homogenized in $0.2 \mathrm{M}$ PCA using a Duall glass grinder and centrifuged at $3000 \times g$ for $20 \mathrm{~min}$ at $4^{\circ} \mathrm{C}$. The PCA-soluble homogenate supernatant was separated from the PCA-insoluble pellet, neutralized with $4 \mathrm{M} \mathrm{KOH}$ and centrifuged at $3000 \times g$ for $20 \mathrm{~min}$ to remove insoluble $\mathrm{KClO}_{4}$ salts. The resulting neutralized supernatant was the PCA-soluble fraction that contained the free amino acid pool; it was further analyzed to determine the specific radioactivity of phenylalanine. The PCA-insoluble pellet precipitated from the tissue homogenate contained protein and predominantly ribosomal RNA; it was washed twice with $0.2 \mathrm{M}$ PCA and solubilized in $0.3 \mathrm{M} \mathrm{NaOH}$ at $37^{\circ} \mathrm{C}$ for $1 \mathrm{~h}$. An aliquot was removed for determination of total protein as described by Smith et al. (14). The remaining solution was acidified with $2 \mathrm{M}$ PCA and centrifuged at $3000 \times g$ for $20 \mathrm{~min}$, and the RNA concentration of the acid-soluble supernatant was determined as described by Munro and Fleck (15). The remaining PCA-insoluble protein pellet was washed again twice with $0.2 \mathrm{M} \mathrm{PCA}$ and hydrolyzed to free amino acids in $6 \mathrm{~N} \mathrm{HCl}$ at $110^{\circ} \mathrm{C}$ for $24 \mathrm{~h}$ under an atmosphere of nitrogen gas. The PCA-soluble (free amino acid pool) and PCA-insoluble (amino acid incorporated into protein) fractions of the liver tissue homogenate were dried under vacuum (Speedvac concentrator-SVC200H; Savant Instruments Inc., Farmingdale, NY), washed three times with water, and resuspended in $\mathrm{H}_{2} \mathrm{O}$ before determination of phenylalanine sp act.

HPLC. Phenylalanine was separated from other amino acids in the samples using anion-exchange chromatography (AS8 column; Dionex Corp., Sunnyvale, CA) as described by Davis et al. (13). Fractions were collected, and the radioactivity associated with the phenylalanine peak was measured in a liquid scintillation counter (TM Analytic, Elk Grove Village, IL).

Calculations. The $\mathrm{K}_{\mathrm{S}}(\% / \mathrm{d})$ was calculated for rats killed 10 min after the injection using the equation (16)

$$
\mathrm{K}_{\mathrm{S}}=\left(S_{\mathrm{B}} / S_{\mathrm{A}}\right) \times(1440 / t) \times 100
$$

where $t$ is the time of labeling in $\min , S_{\mathrm{A}}$ represents the specific radioactivity of phenylalanine in the PCA-soluble tissue free pool, and $S_{\mathrm{B}}$ represents that incorporated into protein. The labeling times used in the calculations are the actual times at which tissues were chilled with ice-cold saline. Because most of the RNA in tissues is ribosomal, the RNA to protein ratio ( $\mu \mathrm{g}$ $\mathrm{RNA} / \mathrm{mg}$ protein) is an estimation of the protein synthetic capacity of the tissue. Translational efficiency was estimated by multiplying the $\mathrm{K}_{\mathrm{S}} \cdot \mathrm{d}^{-1}$ by the ratio of protein to RNA to yield $\mathrm{g}$ protein synthesized per $g$ RNA per $d$. The hepatic protein ASR (mg protein/d) was calculated by multiplying the $\mathrm{K}_{s} \cdot \mathrm{d}^{-1}$ by the protein content (mg protein/liver). The hepatic protein ASR was also calculated relative to EBW because of the significant changes in body weight during development. It was expressed as $\mathrm{mg}$ protein $\cdot \mathrm{d}^{-1} \cdot \mathrm{EBW}^{-1}$ (rASR). In our calculations, EBW represented an animal's live body weight minus the weight of stomach contents. We used EBW rather than live body weight because we found significant differences in stomach contents between fed and fasted rats.

In experiment 2 , at each stage of development, the fractional 
Table 1. Effect of fasting and stage of development on $E B W$ and relative liver weight, protein, and $R N A$ content*

\begin{tabular}{|c|c|c|c|c|}
\hline & \multicolumn{4}{|c|}{ Day postpartum } \\
\hline & 5 & 10. & 16 & 28 \\
\hline \multicolumn{5}{|l|}{$\mathrm{EBW}(\mathrm{g})$} \\
\hline Control (fed) & $10.0 \pm 0.4$ & $20.0 \pm 1.1$ & $34.5 \pm 1.0$ & $78.3 \pm 5.9$ \\
\hline 10-h fasted & $9.8 \pm 0.9$ & $19.8 \pm 0.8$ & $33.4 \pm 1.2$ & $75.9 \pm 5.0$ \\
\hline$\%$ change & $(-3)$ & $(-1)$ & $(-3)$ & $(-3)$ \\
\hline 18-h fasted & $9.6 \pm 0.1$ & $19.5 \pm 1.5$ & $31.3 \pm 1.5$ & $73.9 \pm 10.8$ \\
\hline$\%$ change & $(-4)$ & $(-3)$ & $(-9)$ & $(-6)$ \\
\hline \multicolumn{5}{|c|}{ Liver wt (mg/g EBW) } \\
\hline Control (fed) & $36.2 \pm 1.5$ & $31.5 \pm 2.5$ & $31.3 \pm 2.4$ & $44.0 \pm 2.1$ \\
\hline $10-\mathrm{h}$ fasted & $31.4 \pm 0.9 \dagger$ & $26.9 \pm 0.8 \dagger$ & $26.7 \pm 0.8 \dagger$ & $35.1 \pm 1.7 \dagger$ \\
\hline$\%$ change & $(-13)$ & $(-14)$ & $(-15)$ & $(-20)$ \\
\hline 18-h fasted & $28.4 \pm 0.4 \dagger \ddagger$ & $24.3 \pm 0.3 \dagger \ddagger$ & $27.3 \pm 0.7$ & $34.0 \pm 1.5 \dagger$ \\
\hline$\%$ change & $(-21)$ & $(-23)$ & $(-12)$ & $(-23)$ \\
\hline \multicolumn{5}{|c|}{ Liver protein content $(\mathrm{mg} / \mathrm{g} \mathrm{EBW})$} \\
\hline Control (fed) & $4.51 \pm 0.14$ & $4.46 \pm 0.50$ & $4.29 \pm 0.25$ & $6.84 \pm 0.37$ \\
\hline 10-h fasted & $4.10 \pm 0.19 \dagger$ & $3.98 \pm 0.17$ & $4.10 \pm 0.07$ & $5.94 \pm 0.31 \dagger$ \\
\hline$\%$ change & $(-9)$ & $(-10)$ & $(-4)$ & $(-13)$ \\
\hline 18-h fasted & $3.53 \pm 0.10 \dagger \neq$ & $3.48 \pm 0.17+t$ & $4.15 \pm 0.15$ & $5.87 \pm 0.31 \dagger$ \\
\hline$\%$ change $\S$ & $(-22)$ & $(-21)$ & $(-3)$ & $(-14)$ \\
\hline \multicolumn{5}{|c|}{ Liver RNA content (mg/g EBW) } \\
\hline Control (fed) & $0.334 \pm 0.014$ & $0.272 \pm 0.034$ & $0.270 \pm 0.019$ & $0.385 \pm 0.017$ \\
\hline 10-h fasted & $0.307 \pm 0.006 \dagger$ & $0.244 \pm 0.024 \dagger$ & $0.249 \pm 0.014 \dagger$ & $0.355 \pm 0.021$ \\
\hline$\%$ change & $(-8)$ & $(-10)$ & $(-8)$ & $(-8)$ \\
\hline 18-h fasted & $0.274 \pm 0.007 \dagger \ddagger$ & $0.177 \pm 0.016 t \ddagger$ & $0.232 \pm 0.015 \dagger$ & $0.354 \pm 0.035$ \\
\hline$\%$ change\| & $(-18)$ & $(-35)$ & $(-14)$ & $(-8)$ \\
\hline
\end{tabular}

$*$ Values are means $\pm \mathrm{SD}$. Values in parentheses represent $\%$ change from control fed group.

$\dagger p<0.05$ vs controls.

$\ddagger p<0.05$ vs $10 \mathrm{~h}$.

$\S$ Day postpartum effect $(p<0.05)$.

\| Day postpartum effect (quadratic, $p<0.01$ ).

rate of change in hepatic protein content was determined in the first $10 \mathrm{~h}$ and between 10 and $18 \mathrm{~h}$ of fasting. We used the relative hepatic protein content per unit of EBW rather than the absolute hepatic protein content. The fractional rate of change in hepatic protein content between 0 and $10 \mathrm{~h}$ and 10 and $18 \mathrm{~h}$ of fasting was assumed to be linear and was therefore calculated by dividing the difference in hepatic protein content between the beginning $\left(\mathrm{HP}_{\mathrm{i}}\right)$ and end $\left(\mathrm{HP}_{\mathrm{f}}\right)$ of each interval by the average protein content during each interval:

$$
\left[\left(\mathrm{HP}_{\mathrm{f}}-\mathrm{HP}_{\mathrm{i}}\right) /\left(\overline{\mathrm{X}}_{\mathrm{HP}_{\mathrm{i}}, \mathrm{HP}_{\mathrm{f}}}\right)\right] \times[100 / \Delta \mathrm{t}]
$$

The rates were corrected for the differences in interval duration (i.e. 10 or $8 \mathrm{~h}$ ) and expressed as $\% / \mathrm{h}$. A negative fractional rate of change indicated hepatic protein loss, and a positive fractional rate of change indicated hepatic protein gain.

Statistics. In experiment 1 , differences associated with days postpartum were determined by analysis of variance; comparisons between days postpartum were also determined using $t$ test with a Bonferroni correction for comparison of four means. Polynomial regression was used to analyze changes associated with days postpartum. In experiment 2 , means represents data from three litters; each of the three litter means was calculated using data from two to three rats. Differences associated with day postpartum and fasting time were first analyzed by analysis of variance. In those variables in which there was a significant interaction between days postpartum and fasting time, statistical comparisons between fed, 10-h fasted, and 18-h fasted groups were made using a modified paired $t$ test; the three litters were paired across each treatment, within a given day postpartum. Comparisons between days postpartum were evaluated using Student's $t$ test with a Bonferroni correction for comparison of three means. Polynomial regression was also used to analyze changes associated with days postpartum.

\section{RESULTS}

Experiment 1 . Hepatic RNA/protein ratios decreased linearly $(p<0.05)$ by approximately $47 \%$ between postpartum $d 1$ and 28 , although most of the decrease occurred during the first $5 \mathrm{~d}$ (Fig. 1). The pattern of change in hepatic protein $\mathrm{K}_{S}$ during the first $28 \mathrm{~d}$ postpartum was different from that of the RNA/protein ratio (Fig. 1). Although hepatic tissue $\mathrm{K}_{\mathrm{S}}$ was nearly $40 \%$ lower at birth than at $28 \mathrm{~d}$ postpartum, the pattern of change appeared to be biphasic; $\mathrm{K}_{\mathrm{S}}$ increased (21\%) between postpartum $\mathrm{d} 1$ and 10 , decreased $(30 \%)$ between $d 10$ and 18 , and rose sharply $(67 \%)$ between $\mathrm{d} 18$ and 28 to its highest level $(124 \% / \mathrm{d})$. The biphasic pattern of change in $\mathrm{K}_{\mathrm{s}}$ seen in control (fed) rats was also indicated by the cubic response which approached significance $(p<0.10)$ between postpartum d 5 and 28. During the first 28 d postpartum, the pattern of change observed in hepatic translational efficiency of protein synthesis was quadratic $(p<0.01)$; translational efficiency was greater at d 28 than at $\mathrm{d} 16$. The proportional changes in hepatic translational efficiency, however, were much greater than those found in $\mathrm{K}_{\mathrm{s}}$. Translational efficiency was nearly 3 -fold lower at birth than at $28 \mathrm{~d}$ postpartum; the largest difference was observed during the period normally associated with weaning in rats (16-28 d postpartum).

Experiment 2. EBW did not decrease after either 10 or $18 \mathrm{~h}$ of fasting at any stage of development (Table 1). Liver weights were lower in experimental than in control (fed) rats at postpartum $\mathrm{d} 5,10$, and 28 when measured at 10 and $18 \mathrm{~h}$ of fasting; the only decrease in liver weight among experimental rats occurred on d 16 at $10 \mathrm{~h}$ (Table 1). In addition, liver weight in experimental rats declined significantly at postpartum d 5 and 10 , but not at d 16 and 28 , between 10 and $18 \mathrm{~h}$ of fasting. Liver protein and RNA contents decreased in response to fasting (Table 1). The proportional changes in liver protein and RNA contents at 10 and $18 \mathrm{~h}$ of fasting were similar to those seen in liver weight, except that no changes were found on postpartum d 16 . 


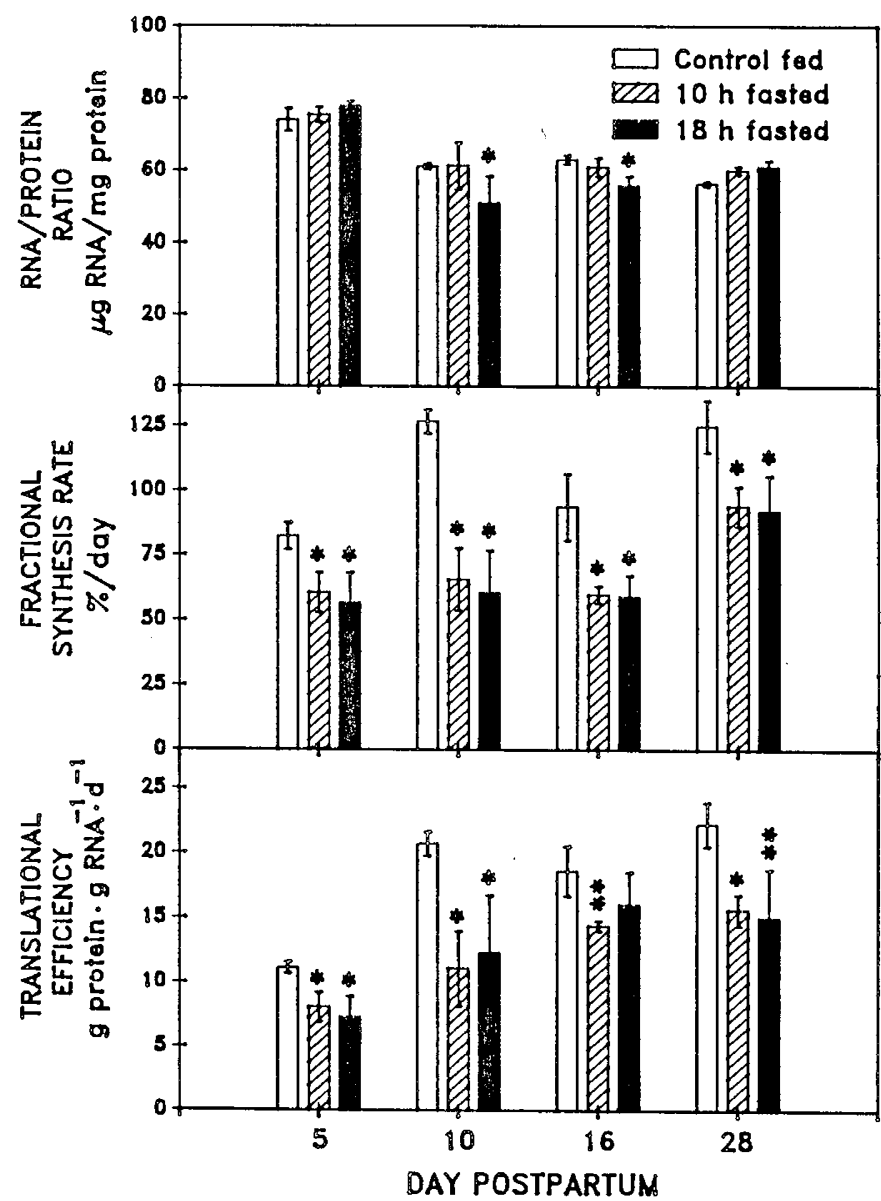

Fig. 2. Changes in hepatic RNA protein ratio, $\mathrm{K}_{\mathrm{S}}$, and translational efficiency in control (fed), 10-h fasted, and 18-h fasted rats during different stages of development. ${ }^{*}$, Different from control (fed) rats $(p<$ $0.01) ;{ }^{* *}$, different from 10 -h fasted rats $(p<0.01)$. RNA protein ratio (postpartum day effect) in control (fed) rats was linear $(p<0.01) ; \mathrm{K}_{\mathrm{S}}$ (postpartum day effect) in control (fed) rats was cubic $(p<0.05)$ and in 10-h and 18-h fasted rats was quadratic $(p<0.05)$; and translational efficiency (postpartum day effect) in control (fed) rats was quadratic ( $p$ $<0.01$ ) and in 10-h and 18-h fasted rats was linear $(p<0.01)$. Bars represent means ( $n=3$ litters) $\pm \mathrm{SD}$. Effects of fasting were analyzed by a paired $t$ test. Postpartum day effects were determined by analysis of variance and polynomial regression.

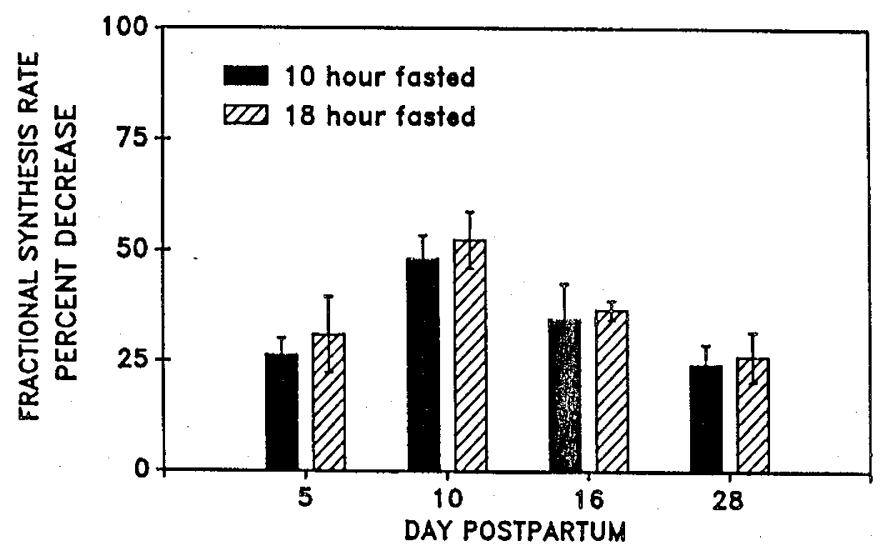

Fig. 3. Percentages of change in $\mathrm{K}_{\mathrm{s}}$ after either 10 (solid bars) or 18 (hatched bars) $\mathrm{h}$ of fasting. Postpartum day effects were determined by analysis of variance for 10 and $18 \mathrm{~h}$ of fasting. Polynomial regression analysis indicated that changes with days postpartum were quadratic ( $p$ $<0.05$ ).
At postpartum d 5 and 10 , but not at d 16 or 28 , there was a significant decline in liver protein and RNA between 10 and 18 $h$ of fasting. The percentage of change in liver protein and RNA content after $18 \mathrm{~h}$ of fasting was greater at postpartum $\mathrm{d} 5$ and 10 than at $\mathrm{d} 16$ and 28 .

In experiment 2, the developmental decline in RNA/protein ratios measured in control (fed) rats was similar to that observed in experiment 1 (Fig. 2). At postpartum d 5 and 28, fasting for either 10 or $18 \mathrm{~h}$ did not influence RNA/protein ratios. On d 10 and 16 , however, the RNA/protein ratio in rats fasted for $18 \mathrm{~h}$ was lower than that in control (fed) rats. As in experiment 1 , hepatic $\mathrm{K}_{\mathrm{s}}$ exhibited a biphasic pattern (cubic $p<0.05$ ) of change between postpartum $\mathrm{d} 5$ and $28 ; \mathrm{K}_{\mathrm{S}}$ increased between $\mathrm{d} 5$ and 10 , decreased between $\mathrm{d} 10$ and 16 , and increased between d 16 and 28 (Fig. 2). At all stages of development, hepatic $\mathrm{K}_{\mathrm{s}}$ in fasted rats was significantly lower than that in control (fed) rats. Most of the decrease in hepatic $\mathrm{K}_{\mathrm{S}}$ occurred in the first $10 \mathrm{~h}$ of fasting: only small decreases were seen with continued fasting for $18 \mathrm{~h}$. The percentage of decline in hepatic $K_{s}$ after either 10 or $18 \mathrm{~h}$ of fasting was greatest at $10 \mathrm{~d}$ postpartum, as indicated by the quadratic effect $(p<0.05)$ with day postpartum (Fig. 3).

Estimates of protein ASR and rASR were calculated to illustrate the changes in whole liver protein synthesis (Table 2 ). The ASR in control (fed) rats was significantly $(p<0.01)$ higher at postpartum d 28 than at $\mathrm{d} 5$. The ASR in control (fed) rats was 3 -fold higher at postpartum d 10 than at $\mathrm{d} 5$ and 4.8 -fold higher at d 28 than at d 16. The ASR, however, was only $24 \%$ lower at d 16 than at d 10. ASR and rASR were significantly lower after 10 or $18 \mathrm{~h}$ of fasting than estimates in control (fed) rats, regardless of stage of development. The rASR increased quadratically $(p<$ 0.01 ) between postpartum d 5 and 28 in rats fasted 10 and $18 \mathrm{~h}$; the largest increases $(2.8$-fold) occurred between d 16 and 28 . The relative decreases in both ASR and rASR after $18 \mathrm{~h}$ of fasting were greatest at $\mathrm{d} 10$ and significantly different from those at postpartum d 28 .

The fractional rates of change in hepatic protein content tended to be lowest at postpartum d 16 (Table 3). At d 5 and 10 , the rate of hepatic protein loss seemed to be greater between 10 and $18 \mathrm{~h}$ than in the first $10 \mathrm{~h}$, whereas at $\mathrm{d} 28$, the rate of loss was greater in the first $10 \mathrm{~h}$ of fasting. The fractional rate of hepatic protein loss between 10 and $18 \mathrm{~h}$ of fasting was greater $(p<0.05)$ at postpartum $\mathrm{d} 5$ and 10 than at either $\mathrm{d} 16$ or $\mathrm{d} 28$.

\section{DISCUSSION}

Developmental changes. Our initial objective was to examine the ontogeny of hepatic protein synthesis during the suckling period. We were particularly interested in the relationship between changes in hepatic protein synthesis and the well-established temporal changes in gene expression, circulating hormone concentrations, and dietary composition. The most striking result that we observed in fed rats from both studies was the biphasic nature of changes in hepatic protein synthesis between postpartum $\mathrm{d} 1$ and 28 , i.e. the protein $\mathrm{K}_{\mathrm{s}}$ increased between $\mathrm{d}$ 1 and 10 , decreased slightly between $\mathrm{d} 10$ and 16 , and increased between $\mathrm{d} 16$ and 28 .

The increase in hepatic $K_{s}$ by $d 10$ coincided with the reported increase in gluconeogenic and ketogenic enzyme expression (3, 4). The reason for the decline in hepatic $K_{s}$ between $d 10$ and 16 is less clear; it occurred, however, in both experiments 1 and 2. We have found (17), as have others (18), that the energy and protein intakes of suckling rats decline between $d 10$ and 16 and are associated with a decrease in the fractional rate of weight gain. Thus, the transient decline in hepatic $K_{s}$ between $d 10$ and 16 may be a consequence of a progressively limited nutrient intake.

The increase in all estimates of protein synthesis between postpartum d 16 and 28 is concurrent with the transition from milk to solid food. During this time, the liver also makes its maximum contribution to body protein mass (19). In our study, 
Table 2. Effect of fasting and stage of development on liver protein ASR*

\begin{tabular}{|c|c|c|c|c|}
\hline \multirow[t]{2}{*}{. } & \multicolumn{4}{|c|}{ Day postpartum } \\
\hline & 5 & 10 & 16 & 28 \\
\hline \multicolumn{5}{|c|}{ ASR (mg protein/d) } \\
\hline 10-h fasted & $24.26 \pm 4.0 \dagger$ & $52.0 \pm 12.8 \dagger$ & $81.6 \pm 1.8 \dagger$ & $422.6 \pm 26.2 \dagger$ \\
\hline$\%$ change & $(-35)$ & $(-54)$ & $(-41)$ & $(-37)$ \\
\hline 18-h fasted & $19.12 \pm 4.5 \dagger$ & $42.1 \pm 15.7 \dagger$ & $77.5 \pm 16.1 \dagger$ & $397.4 \pm 99.1 \dagger$ \\
\hline$\%$ change & $(-49)$ & $(-62)$ & $(-44)$ & $(-40)$ \\
\hline 10-h fasted $\|$ & $2.48 \pm 0.20 \pi$ & $2.63 \pm 0.32 \dagger$ & $2.44 \pm 0.06 \dagger$ & $5.56 \pm 0.319$ \\
\hline$\%$ change & $(-34)$ & $(-53)$ & $(-40)$ & $(-36)$ \\
\hline 18-h fasted $\|$ & $1.99 \pm 0.27 \dagger$ & $2.16 \pm 0.37 \dagger$ & $2.47 \pm 0.24 \dagger$ & $5.38 \pm 0.34 \pi$ \\
\hline$\%$ changef & $(-47)$ & $(-62)$ & $(-40)$ & $(-37)$ \\
\hline
\end{tabular}

* Values are means $\pm \mathrm{SD}$. Numbers in parentheses represent $\%$ change from control fed group.

$\dagger p<0.05$ vs controls.

$\ddagger$ Day postpartum effect $(p<0.05)$.

$\S$ Day postpartum effect (cubic, $p<0.05$ ).

$\|$ Day postpartum effect (quadratic, $p<0.05$ ).

If $p<0.01$ vs controls.

Table 3. Effect of stage of development on fractional rate of change in hepatic protein content between 10- and 18-h intervals of fasting*

\begin{tabular}{ccccc}
\hline & \multicolumn{5}{c}{ Day postpartum } \\
\cline { 2 - 5 } & 5 & 10 & 16 & 28 \\
\hline Fasting interval $(\mathrm{h})$ & & & & \\
$0-10$ & $-0.96 \pm 0.15$ & $-1.09 \pm 0.70$ & $-0.43 \pm 0.30$ & $-1.42 \pm 0.35$ \\
$10-18 \dagger$ & $-1.85 \pm 0.49$ & $-1.67 \pm 0.29$ & $+0.15 \pm 0.23$ & $-0.14 \pm 0.14$ \\
\hline
\end{tabular}

$*$ Values $(\% / h)$ are means \pm SD. Positive $(+)=$ gain; negative $(-)=$ loss. Rates are calculated as described in Materials and Methods.

$\dagger$ Day postpartum effect $(p<0.01)$.

the rASR at $\mathrm{d} 28$ (8.53) was significantly higher than at any earlier stage of development (3.71 to 5.60). Although the energy intakes (kcal/body wt) of suckling rats at postpartum $\mathrm{d} 16$ and weaned rats at $\mathrm{d} 28$ are similar $(17,20)$, between $\mathrm{d} 16$ and 28 the composition of dietary energy changes from predominantly fat to predominantly carbohydrate. As the intake of dietary carbohydrate increases during weaning, both plasma corticosterone concentrations and tissue responsiveness to corticosterone also increase (4). Studies in young, growing, weaned rats suggest that corticosterone can stimulate hepatic protein synthesis (7). A direct link between the surge in plasma corticosterone concentrations and the increase in hepatic protein synthesis has not been established. Nevertheless, the increase in hepatic protein synthesis is consistent with a surge of new enzyme expression (3) that reflects the change in hepatic metabolic function in response to increased carbohydrate intake.

Effects of fasting. The neonate may be particularly vulnerable to the effects of acute nutritional deprivation because of its inherent metabolic fragility. Because hepatic metabolic function depends on the relative expression of enzymes, the conservation of hepatic protein is crucial to sustained metabolic function during acute nutritional deprivation. Our results indicate that during acute fasting, hepatic protein was reduced as a result of decreased protein synthesis. The relative magnitude of these changes seemed to be greater during the neonatal (especially postpartum d 10) than during the late suckling or weaning periods.

Regardless of the stage of development, hepatic protein $\mathrm{K}_{\mathrm{S}}$ and ASR decreased in response to fasting. Most of the decrease occurred within the first $10 \mathrm{~h}$ and was accompanied by significantly reduced liver weight and protein and RNA content. Despite these changes, there was no significant decrease in EBW. With few exceptions, hepatic RNA/protein ratios were unaffected by fasting. Thus, decreased hepatic $\mathrm{K}_{\mathrm{S}}$ was largely a result of decreased translational efficiency rather than a decrease in ribosomal number.

The effects of fasting on hepatic protein synthesis in the suckling rats in our study were qualitatively similar to those reported in adult and young weaned rats $(8-10)$. We found quantitative differences, however, depending on the stage of development. Regression analysis of the percentage of change in $\mathrm{K}_{\mathrm{s}}$ after either 10 or $18 \mathrm{~h}$ of fasting indicated that the change at postpartum d 10 was larger than that at either d 16 or 28 . In addition, the relative decreases in hepatic $\mathrm{K}_{\mathrm{s}}$ in suckling rats fasted for $18 \mathrm{~h}$ ranged from 25 to $52 \%$ compared with 17 to $28 \%$ reported in young, growing animals fasted for 24 to $48 \mathrm{~h}(9,10)$. We were concerned about a potential effect of differences in the stomach emptying rate in fasted rats at different stages of development. At d 5, 10, and 16, the rates of stomach emptying were similar (approximately 20\%/h); at d 28, however, they were significantly higher $(40 \% / \mathrm{h})(21)$. Nevertheless, on all days measured, the stomachs were approximately $90 \%$ empty after $4 \mathrm{~h}$ of fasting. Taken together, these findings suggest that the relative decrease in hepatic protein synthesis in response to fasting was greater in 10-d-old neonatal rats than in older suckling or weaned rats.

Alternatively, one could hypothesize that the rate of hepatic protein synthesis during fasting was the "basal rate" and that the differences in hepatic protein synthesis rate associated with stage of development resulted from changes in the sensitivity and/or responsiveness of the liver to nutrient intake. Two findings support this speculation: first, we found that the values for hepatic $\mathrm{K}_{\mathrm{s}}$ and rASR on $\mathrm{d} 5,10$, and 16 after either 10 or $18 \mathrm{~h}$ of fasting were remarkably similar, approximately $60 \% / \mathrm{d}$ and $2.40 \mathrm{mg} \cdot \mathrm{d}^{-1} \cdot \mathrm{g} \mathrm{EBW}^{-1}$. These values support the premise that a basal rate of hepatic protein synthesis attained in suckling rats after $10 \mathrm{~h}$ of fasting may have been related to the maintenance of vital metabolic functions; the basal rate of protein synthesis, 
however, was higher after weaning than during the suckling period. Second, we found that food intake and stage of development may have affected the degree to which hepatic protein synthesis was increased above the basal rate. Hepatic protein synthesis decreased in the fed state between $\mathrm{d} 10$ and 16 , as the nutrient intake of the suckling pups was reduced. As a result, the relative decrease in hepatic protein synthesis in response to fasting at postpartum d 16 was smaller than that at $d 10$. The relative differences in the fed and fasted states at postpartum $\mathrm{d}$ 16 and 28 were similar, despite significant increases in the hepatic protein ASR in both the fed and fasted rats during this period. Thus, the relative differences in hepatic protein synthesis between fed and fasted rats reflected relative differences in nutrient stimulation in the fed state, as well as the basal level of protein synthesis at a given stage of development.

Changes in protein synthesis, however, could not account for the total reduction in hepatic protein content in response to fasting. The changes in hepatic protein content at either 10 or $18 \mathrm{~h}$ of fasting were influenced by stage of development. At postpartum d 5 and 10 , the absolute decrease in hepatic protein content was linear between 0 and $18 \mathrm{~h}$ of fasting. On the other hand, at postpartum d 16 and 28 , most of the decrease in protein content occurred in the first $10 \mathrm{~h}$, with no further significant decrease between 10 and $18 \mathrm{~h}$. Although the fractional rate of hepatic protein loss seemed to increase with the duration of fasting in neonatal rats at postpartum $\mathrm{d} 5$ and 10 , it declined in 28 -d-old weaned rats. These data, combined with the fact that the decline in protein synthesis was essentially completed by 10 $\mathrm{h}$ of fasting, suggest that protein content may have been regulated by degradation rather than synthesis after $10 \mathrm{~h}$.

We conclude that developmental changes in hepatic protein synthesis in the rat are biphasic. We documented increases in hepatic protein synthesis between birth and $10 \mathrm{~d}$ and again after weaning. The increases are associated with temporal changes in enzyme expression, diet composition, and circulating hormone concentrations that have been reported to occur during the neonatal and late suckling or weaning periods. The differences in the response to fasting with stage of development appeared to reflect differences in the responsiveness of hepatic protein synthesis to nutrient intake above a basal rate. This basal rate was relatively constant during the suckling period and increased after weaning. Nevertheless, reduced protein synthesis, combined with a greater fractional rate of hepatic protein loss, contributed to the greater proportional decrease in protein mass in neonatal rats than in older weaned rats. Thus, if hepatic function is linked to protein mass, our results suggest that metabolic function may be more compromised in response to fasting in the neonatal rats than in older weaned animals.

Acknowledgments. The authors thank K. Gravitt, H. Nguyen, and M. Perez for their expert technical assistance, R. Schoppa and C. Fedrick for manuscript preparation, and J. D. Eastman for editorial review.

\section{REFERENCES}

1. Winick M, Noble A 1965 Quantitative changes in DNA, RNA, and protein during prenatal and postnatal growth in the rat. Dev Biol 12:451-466

2. Greengard O, Ferderman M, Knox WE 1972 Cytomorphometry of developing rat liver and its application to enzymic differentiation. $\mathrm{J}$ Cell Biol 52:261272

3. Greengard O 1970 The developmental formation of enzymes in rat liver. In: Litwack $G$ (ed) Biochemical Actions of Hormones. Academic, New York, pp 53-87

4. Henning SJ 1981 Postnatal development: coordination of feeding, digestion, and metabolism. Am J Physiol 241:G199-G214

5. Goodridge AG 1987 Dietary regulation of gene expression: enzymes involved in carbohydrate and lipid metabolism. Ann Rev Nutr 7:157-185

6. Little ME, Hahn P 1990 Diet and metabolic development. FASEB J 4:26052611

7. Southorn BG, Palmer RM, Garlick PJ 1990 Acute effects of corticosterone on tissue protein synthesis and insulin-sensitivity in rat in vivo. Biochem $\mathrm{J}$ 272:187-191

8. Preedy VR, Paska L, Sugden PH, Schofield PS, Sugden MC 1988 The effects of surgical stress and short-term fasting on protein synthesis in vivo in diverse tissues of the mature rat. Biochem J 250:179-188

9. McNurlan MA, Fern EB, Garlick PJ 1982 Failure of leucine to stimulate protein synthesis in vivo. Biochem J 204:831-838

10. McNurlan MA, Tomkins AM, Garlick PJ 1979 The effect of starvation on the rate of protein synthesis in rat liver and small intestine. Biochem J 178:373379

11. Bailee AG, Maltin CA, Garlick PJ 1988 The effect of fasting and insulin infusion on muscle protein synthesis in immature and adult rats. Proc Nutr Soc 47:114A (abstr)

12. Davis TA, Fiorotto ML, Nguyen HV, Reeds PJ 1989 Protein turnover in skeletal muscle of suckling rats. Am J Physiol 257:R1141-R1146

13. Davis TA, Fiorotto ML, Nguyen HV, Burrin DG, Reeds PJ 1991 The response of muscle protein synthesis to fasting in suckling and weaned rats. Am J Physiol (in press)

14. Smith PK, Krohn RI, Hermanson GT, Mallia AK, Gartner FH, Provenzano MD, Fujimoto EK, Goeke NM, Olson BJ, Klenk DC 1985 Measurement of protein using bicinchoninic acid. Anal Biochem 150:76-85

15. Munro HN, Fleck A 1969 Analysis for nitrogenous constituents. In: Munro HN (ed) Mammalian Protein Metabolism. Academic, New York, pp 465483

16. Garlick PJ, McNurlan MA, Preedy VR 1980 A rapid and convenient technique for measuring the rate of protein synthesis in tissues by injection of $\left[{ }^{3} \mathrm{H}\right]$ phenylalanine. Biochem J 192:719-723

17. Fiorotto ML, Burrin DG, Perez M, Reeds PJ 1991 Intake and use of milk nutrients by rat pups suckled in small, medium, or large litters. Am $\mathbf{J}$ Physiol 260:R1104-R1113

18. Babicky A, Parizek J, Ostadalova I, Kolar J 1973 Initial solid food intake and growth of young rats in nests of different sizes. Physiol Bohemoslov 22:557566

19. Miller SA 1969 Protein metabolism during growth and development. In: Munro HN (ed) Mammalian Protein Metabolism. Academic, New York, pp 183-233

20. Ferrell CL, Koong KJ 1986 Influence of plane of nutrition on body composition, organ size and energy utilization of Sprague-Dawley rats. J Nutr 116:2525-2535

21. Davis TA, Fiorotto ML, Nguyen HV, Burrin DG, Reeds PJ 1990 The rapid decline in muscle protein synthesis during fasting in young suckling rats is associated with changes in plasma insulin. FASEB J 5:A922 (abstr) 